THE EXTENSION OF THE PHISICAL AND ELECTROTECHNICAL LABORATORIES OF THE UNIVERSITY OF MANCHESTER.

' $\mathrm{HE}$ new extension of the physical and electrotechnical laboratories of the University of Manchester was formally opened on Friday evening, March I, by Prof. Schuster, F.R.S. A well-attended reception and conversazione was held on Friday evening in the old and new laboratories. Many interesting experiments and exhibits of apparatus were on view during the conversazione and on Saturday morning. In the course of the evening a meeting was held in the large lecture theatre. The ViceChancellor, Sir Alfred Hopkinson, referred to the growth of the work in the physical laboratory and the necessity of providing more space for research. Mr. S. Z. de Ferranti, president of the Institution of Electrical Engineers, was awarded the honorary degrec of doctor of science. Prof. Lamb, in presenting Mr. Ferranti to the Vice-Chancellor, said that more than a quarter of a century ago he attacked the problem of the transmission of electrical energy in its most concentrated form, and, undaunted by discouragements and prophecies of disaster, he solved it in practice on a commercial scale with complete success. It was largely to his initiative and his labours that we owed the plentiful use of the light which supplemented and often, alas! superseded and surpassed the sunshine of Manchester.

Prof. Schuster, before declaring the new buildings opened, addressed the meeting, and described the development of the physical department of the University. In a subsequent portion of his address he spoke of the great field for the student of physics in India and the colonies.

When the main physical laboratories were built in I90o, a large part of one floor was set aside for the department of electrical engineering, while a special laboratory, known as the John Hopkinson Dvnamo Laboratory, was built. The steady growth of the department and the increase of the number of those engaged in original investigation have, in recent years, placed great pressure on the space of the laboratory. This was emphasised by the nature of many of the researches in radio-activity, in which large quantities of radium are employed. The effect of the $\gamma$ rays, which are able to traverse the walls and floors of the laboratory, disturbed thr measurements of the workers not only in the immediate vicinity, but also in the neighbouring rooms. In order to provide additional space, the Council of the University decided to remove the department of electrical engineering from the physical laboratory proper and to locate it in a new building. In these new engineering laboratories, part of the first floor, containing six research rooms, has bcen set aside for physics, while a small electrochemical laboratory has been erected outside for work on radio-active substances. The physics department has thus the use of the space formerly occupied by electrical engineering. The addition of a number of new research rooms for physics, removed some distance from the main phrsical laboratory will prove of great advantage for the purpose of original investigation, especially for radio-activity and allied subjects. It is intended to keep the new laboratories uncontaminated by radio-active matter, and they will be employed mainly for the more delicate measurements.

The new buildings were designed by Mr. I. W. Beaumont the architect of the main physical laboratories. They form a simple but substantial structure faced externally in red Ruabon brick with stone dressings so as to harmonise with the main physics buildings.

NO. 22 I I, VOL. 89]
A noteworthy feature of the new buildings is the system of bare wires run on insulators, which has been adopted throughout for the experimental circuits. This system has proved so satisfactory in the main laboratory that it has been employed wherever possible in the present extension. From the battery, which is of 600 ampere-hour capacity, with a maximum discharge rate of 300 amperes, heavy bare copper conductors run along a subway beneath the main corridor to the switchboard room in the north wing. From this, by means of plug boards, current can be distributed over the whole building.

\section{CALENDAR REFORM}

$\mathrm{A} \mathrm{N}$ article by Mr. Victor Anestin, of Bukarest, on calendar reform in the States of the Greek Church, extracted from A. Richter's "Kalender" (Riga, I912), has been received. The author gives an interesting account of the efforts which have been made in the Balkan States and in Greece towards the adoption of the Gregorian calendar, and describes the state of public opinion on the question at the present time. It is a pathetic story of ecclesiastical prejudice and jealousy on one side and political irresolution and instability on the other. The chief obstacle to following the practice of western Europe lies in the fear entertained by each national church of being denounced as schismatic by the other adherents of the Greek faith, and this prevents any one of the churches, though nominally independent, from taking the lead and sanctioning the reform. Hence the outlook at present is not promising. Mr. Anestin expresses the opinion that the fate of the reform in these States depends on the action of Russia, since the other Greek churches would not be likely to impugn the Russian church, but would prohably follow its initiative. In the meantime, the matter does not advance. Roumania seems to have sone further than the other States, and though a Bill enacting the change which was presented to the Chamber came to nothing owing to the political circumstances of the time, the postal and telegraph services and the railways use the Western calendar, and all the almanacs show both styles side by side.

A certain value in the existence of two calendars is suggested by the following quite charming story which happens to appear in close juxtaposition to Mr. Anestin's article, and, if not bearing seriously on the question, may be reproduced as an interesting niece of folklore. It appears that the ginsies of Servia and Montenegro go in fear of the evil spirits which are abroad at Christmas. Therefore an old gipsv living on the Hungarian-Servian border has devised this subtle means of protecting himself. On Christmas Dav (N.S.) he hangs up in his hut a Servian (O.S.) calendar; thus any prowling demons will see at once that he is a Serb, and as such observes the Tulian Christmas. Thirteen days later he hangs up a Hungarian (Western) calendar; and then, of course, the evil snirits will recognise their powerlessness over him since. so far as he is concerned, Christmas is alreadv a thing of the past.

H. C. P.

\section{FORTHCOMING BOOKS OF SCIENCE. Agriculture.}

Baillière, Tindall and Cox.-Fungoid Diseases of Agricultural Plants, Prof. Eriksson (translated from the Swedish). Cambridge University Press.-Soil Fertility, Dr. E. J. Russell; a series of Monographs on Agricultural Science, under the editorship of Prof. T. B. Wood and Dr. E. J. Russell; a series (also edited by Prof. T. B. Wood and Dr. E. J. Russell) 
entitled "The Farm Institute Series." Cassell and Co., Ltd.-Dairying, Prof. J. P. Sheldon, illustrated. Methuen and Co., Ltd.-Bacteria as Friends and Foes of the Dairy Farmer, W. Sadler, illustrated; Progressive Poultry Culture, Dr. A. A. Brigham, revised by S. C. Sharpe, illustrated.

\section{ANTHROPOLOGY.}

Cambridge University Press.-The Phœnicians, Prof. J. L. Myres; The Vikings, Prof. A. Mawer. Hodder and Stoughton.-The Individual Family of the Australian Aborigines, Dr. Malinovski. Macmillan and Co., Ltd.-The Golden Bough: a Study in Magic and Religion, Dr. J. G. Frazer, third edition, in seven parts, Part v., Spirits of the Corn and of the Wild; The Lushei Clans, ILieut.-Col. J. Shakespear, C.I.E., D.S.O.; The Mafulu Mountain People of British New Guinea, R. W. Williamson, with an introduction by Dr. A. C. Haddon, F.R.S., illustrated. John Murray.-The Excavation of Gezer, $1902-5$ and I907-9, Prof. R. A. S. MacAlister, 3 vols., illustrated. Iregan Paul and Co., Ltd.-Legends of the Gods, the Egyptian Texts, edited with translations, Dr. E. A. W. Budge, illustrated; Annals of the Nubian Kings, with a Sketch of the History of the Nubian Kingdom of Napata, Dr. E. A. W. Budge, illustrated.

\section{BIOLOGY.}

D. Appleton and Co.-Heredity in Relation to Evolution and Animal Breeding, Prof. W. E. Castle. John Bale, Sons and Danielsson, Ltd.-Coconuts: the Consols of the East, H. Smith and F. A. G. Pape. $A$. and $C$. Black.-How to Use the Microscope, Rev. C. A. Hall, illustrated; British Ferns, Clubmosses, and Horse-tails, D. Ferguson; British Butterflies, A. M. Stewart; Natural History of the Garden, P. Westell; The Grammar of Science, Prof. Karl Pearson, F.R.S., new edition, illustrated, part ii., Biological. Gebrüder Borntraeger (Berlin).-Die Anschauungen V. Hehns von der Herkunft unserer Kulturpflanzen und Haustiere im Lichte neuerer Forschung; Bestimmungsbuch der Vögel Mitteleuropas, Prof. F. Dahl, illustrated; Anleitung zur mikroskopischen Untersuchung von Pflanzenfasern, Dr. G. Tobler-Wolff und Prof. F. Tobler, illustrated; Milkroscopisches Praktikum für systematische Botanik (I. : Angiospermen), Prof. M. Möbius, illustrated; Laubfall und Lauberneuerung in den Tropen, Prof. G. Volkens; Symbolae Antillanae seu fundamenta florae Indiae Occidentalis, edited by I. Urban, vol. vii., fasc. I; Flora von Steiermark, Dr. A. von Hayek, Band ii., Heft 2 und 3; Kryptogamenflora der Mark Brandenburg, Band v., Heft 4, M. v. Minden. Cambridge University Press. - The New Field Botany, Dr. C. E. Moss; Spiders, C. Warburton; Flies, Dr. Gordon Hewitt; The Green Leaf, Dr. F. F. Blackman, F.R.S.; Growth and Form, Prof. D'Arcy W. Thompson, C.B.; Individuality in the Animal Kingdom, J. Huxley; Eugenics, Prof. R. C. Punnett; Insects as Carriers of Disease, Prof G. H. F. Nuttall, F.R.S.; The Gateways of Knowledge, J. A. Dell (Cambridge Nature Study Series). Cassell and Co., Ltd.-Practical Rabbit-keeping, G. A. Townsend, illustrated; The Nature Book, in thirty-six fortnightly parts, illustrated; British Birds' Nests: How, Where and When to Find and Identify Them, R. Kearton, in seventeen fortnightly parts, illustrated. Gustav Fischer (Jena).-Das kleine pflanzenphysiologische Praktikum, Prof. W. Detmer, new edition, illustrated; Verhandlungen des VIII. Internationalen Zoologen-Kongresses in Graz, illustrated; Untersuchungen über Propfbastarde, Prof. H. Winkler, i. Teil, illustrated. Gurney and Jackson.-Studies in Bird Migration, NO. 22 I I, VOL. 89$]$
W. Eagle Clarke, illustrated; A History of British Mammals, G. E. H. Barrett-Hamilton, Part x., The Rabbit (Genus Oryctologus), Part xi., Squirrel (Genus Sciurus), Part xii., the Hare (Genus Lepus), illustrated; a new and revised edition of Yarrell, Newton, and Saunders' History of British Birds, edited by W. Eagle Clarke, illustrated. W. Heffer and Sons, Ltd. (Cambridge).-A Monograph on British Violets, Mrs. E. S. Gregory, illustrated. W. Heinemann.Animal Life in Africa, Major J. S. Hamilton, illustrated; Microbes and Toxins in Nature, Dr. E. Burnet, translated by Drs. C. Broquet and IV. M. Scott, illustrated. H. Holt and Co. (New York). -Key to the Wild and Commonly Cultivated Trees of the North-eastern Lnited States and Adjacent Canada, J. F. Collins and H. W. Preston; The Living Plant, W. F. Ganong; American Woods, E. C. Jeffrey and I. W. Bailey; Useful Plants: their Properties and Kinship, F. L. Sargent. T.C. and E. C. Jack.-Bees, E. Hawks, illustrated; Embryology - the Beginnings of Life, Dr. G. Leighton; Biology-the Science of Life, Dr. IV. D. Henderson; Animal Life, Prof. E. W. MacBride, F.R.S.; Bacteriology, Dr. W. E. C. Dickson; Evolution, E. S. Goodrich, F.R.S.; Darwin, Prof. W. Garstang; Huxley, Dr. G. Leighton; Annuals, C. H. Curtis, illustrated; Chrysanthemums, T. Stevenson, with chapters by C. E. Shea and C. H. Payne, illustrated; Tulips, Rev. J. Jacob, illustrated; The Rockery, R. Farrar, illustrated; Dahlias, G. Gordon, illustrated. C. H. Kelly.--Moths and How to Identify Them, S. N. Sedgwick, illustrated. Longmans and Co.The Life of the Plant, Prof. C. A. Timiriaseff, translated from the corrected seventh Russian edition by Miss A. Cheremeteff, illustrated. Macmillan and Co., Ltd.-The Depths of the Ocean based on the Scientific Researches of the Norwegian Steamer, Michael Sars, in the North Atlantic, Sir J. Murray, K.C.B., F.R.S., and Dr. J. Hjort, assisted by Prof. Gran and Dr. H. Hansen, illustrated. Methuen and Co., Ltd. -Reptiles, Amphibia, and Fishes, R. Lydekker, F.R.S., and others, illustrated; British Plant Galls: a Classified Text-book of Cecidology, E. W. Swanton, with a preface by Sir Jonathan Hutchinson, F.R.S., illustrated; Alpine Flora, H. Conevon, translated and enlarged by E. W. Clayforth, illustrated. Milner and Co.-Botany: some Chapters on the Study of Plants, Prof. G. S. Boulger, illustrated. John Murray.-The Genus Rosa, E. Willmott, in parts, illustrated; Problems of Life and Reproduction, Prof. M. Hartog; illustrated (Progressive Science Series). Quelle and Meyer (Leipzig).-Allgemeine Botanik, Prof. A. Nathansohn, illustrated; Süsswasserfische Mitteleuropas, Dr. 亡. Walther; Unsere Wasserinselsten, G. Ulmer, illustrated; Vorgeschichte der Pflanzenwelt, Dr. W. Gothan, illustrated. Alston Rivers,
Ltd.-British Plants : their Biology and Ecology, Ltd.-British Plants: their Biology and Ecology,
I. F. Bevis and H. J. Jeffery, illustrated. G. Routledge and Sons, Ltd. A A Popular Dictionary of Botanical Names and Terms, with their English Equivalents, G. F. Zimmer, in two parts: i., Specific Names, ii., Family Names; The Gardener's Dictionary, edited by A. Hemsley and J. Fraser, illustrated; Sub-Alpine Plants: Flowers of the Swiss Meadows, Woods, and Plains, H. Stuart Thompson, illustrated. Smith, Elder and Co.- The Grouse in Health and in Disease, new and cheaper abridged edition, illustrated. The Universitv Tutorial Press, Ltd.-School Lessons in Plant and Animal Life: a Guide to Teachers, with Suggestions for Eighty Lessons, arranged according to Seasons, Dr. I. Rennie. T. Fisher Unwin.Butterflies and Moths at Home and Abroad, H. R. Brown, illustrated. J. Wiley and Sons (Neae York).-Practical Forestry for New England, 
Profs. R. C. Hawley and A. F. Hawes. Witherby and Co.-The Game-birds and Waterfowl of South Africa, Major B. Horsbrugh, in four parts, illustrated; A Hand-list of British Birds, E. Hartert, the Rev. F. C. R. Jourdain, N. F. Ticehurst, and H. F. Witherby; The Birds of Australia, G. M. Mathews, vol. ii., Part i., illustrated; Flight of Birds, F. W. Headley.

\section{Chemistry.}

Edward Arnold.-The Chemistry of Bread-making, J. Grant; Smolse : a Study of Town Air, Prof. J. B. Cohen, F.R.S., and A. G. Ruston, illustrated. Cambridge University Press.-Brewing, A. C. Chapman; The Story of a Loaf of Bread, Prof. T. B. Wood. Constable and Co., Ltd.-An Introduction to the Study of Fuel, Dr. F. J. Brislee; The Chemistry of the Rubber Industry, H. E. Potts; The Chemistry of Dyeing and Bleaching of Vegetable Fibrous Materials, J. Hubner, each illustrated. Gurney and Jackson.-The Manufacture of Sulphuric Acid and Alkali, Prof. G. Lunge, vol. i., Sulphuric Acid, new edition, vol. iv., Preparation of Alkali, \&c., by Electrolysis; Technical Methods of Chemical Analysis, Prof. G. Lunge and Dr. C. A. Keane, vol. iii. W. Heinemann.--Experimental Domestic Science, R. H. Jones. T. C. and E. C. Jack.-Chemistry of Non-living Things, Prof. E. C. C. Baly, F.R.S. Longmans and Co.-A Dictionary of Applied Chemistry, Prof. Sir Edward Thorpe, C.B., F.R.S., assisted by eminent contributors, revised and enlarged edition, vol. ii., illustrated. Methuen and Co., Ltd..-Modern Research in Organic Chemistry, F. G. Pope, illustrated; Oualitative Organic Analysis, F. B. Thole, illustrated; A Practical Chemistry for Technical Institutes, Dr. A. E. Dunstan and F. B. Thole, illustrated; Second Year Organic Chemistry for Schools and Technical Institutes, F. B. Thole, illustrated. Mills and Boon, Ltd.-Problems in Practical Chemistry for Advanced Students, G. F. Hood, illustrated. I. Wiley and Sons (New York).-A Summary of Methods in Chemical Analysis, Prof. F. A. Gooch.

\section{ENGINEERING.}

Edward Arnold.-The Theory and Design of $\mathrm{Re}$ inforced Concrete, O. Faber and P. G. Bowie, illustrated. Constable and Co., Ltd.--American Electric Central Station Distribution Systems, H. Barnes Gear and P. F. Williams, illustrated; The Energy Diagram for Gas, Prof. F. W. Burstall; Railway Signalling Engineering, L. P. Lewis, illustrated; Modern Sanitary Engineering, G. Thomson, illustrated; a new edition of Irrigation, Sir H. Brown. Gauthier-Villars (Paris)._-La formation des Ingénieurs électriciens, Prof. A. Blondel; Les nomogrammes de 1'Ingénieur, $R$. Seco de la Garza. Longmans and Co.-Elementary Internal Combustion Engines, J. W. Kershaiv, illustrated; The Mechanics of the Aëroplane: a Text-book, Capt. Duchene, translated from the French by J. $\mathrm{H}$. Ledeboer and T. O'B. Hubbard, illustrated. G. Routledge and Sons, Ltd.-The Control of Water for Power, Irrigation, and Town Water-supply Purposes, P. à M. Parker, illustrated. J. Wiley and Sons (New York).-Subways and Tunnels of New York: Methods and Cost, with an Appendix on Tunnelling Machinery and Methods and Tables of Engineering, G. H. Gilbert, L. I. Wightman, and W. L. Saunders, illustrated; Practical Methods of Sewage Disposal for Residences, Hotels, and Institutions, Prof. H. N. Ogden and H. B. Cleveland; Design of Electrical Machinery, Prof. W. T. Ryan, in three volumes, illustrated; The Design and Construction of Roofs, Prof. N. C. Ricker; Cost of Concrete, Dr. F. W. Taylor and S. E. Thompson; NO. 22 I I, VOL. 89]
Laboratory Manual for the Use of Students in Testing Materials of Construction, Prof. L. A. Waterbury, illustrated.

\section{Geography and Travel.}

$A$. and $C$. Black.-.The World (Regional Geocraphy), J. B. Reynolds, illustrated; Man and his Conquest of Nature, Dr. M. I. Newbigin, illustrated; Geographical Pictures: Land Forms and how They are Made, Series iii., The Sculpture of the Surface, edited by S. M. Nicholls, in two packets; Historical Geography of the British Isles, M. S. Elliott, illustrated; Elementary Picture Geography Series: How Other People Live, H. C. Barnard, illustrated; The Children's World, S. Shenessey, illustrated. W. Blackwood and Sons.-Chiefs and Cities of Central Africa: Across Lake Chad by Way of British, French, and German Territories, O. Macleod, illustrated. Cambridge University Press.--Physical Geography for South African Schools, A. L. du Toit; Cambridge Geographical Text-books-Junior, A. J. Dicks; Cambridge County Geographies: Oxfordshire, P. H. Ditchfield; West London, G. F. Bosworth; Breconshire, C. J. Evans; North Lancashire, Dr. J. E. Marr, F.R.S.; Radnorshire, L. Davies; Dunfriesshire, Rev. Dr. J. K. Hewison; Perthshire, P. Macnair; Renfrewshire, F. Mort. GauthierVillars (Paris).-Guide scientifique du géographe explorateur, C. de Beauregard. W. Heincmann.Animal Life in Africa, Major J. Stevenson-Hamilton. H. Holt and Co. (New York).-Elements of Geography, R. D. Salisbury, H. H. Barrows, and W. S. Tower. Macmillan and Co., Ltd.-Across Australia, Prof. B. Spencer, C.M.G., F.R.S., and F. J. Gillen, illustrated. A. Melrose.-Big Game Hunting in Central Africa, Dr. J. D. Brunton, illustrated. Kegan Paul and Co., Ltd.--A Vovage to the Arctic in the Whaler Aurora, D. M. Lindsay, illustrated. G. P. Putnam's Sons.-In the Amazon Jungle: Adventures in a Remote Part of the Upper Amazon River, including a Sojourn among the Cannibal Indians, A. Lange, illustrated.

\section{Geology.}

A. and C. Black.-Romance of the Rocks, Rev. C. A. Hall, illustrated. Gebrïder Borntraeger (Berlin).-Geologischer Führer durch die nördliche Adria, Dr. R. Schubert, illustrated; Petrographisches Praktikum, Prof. R. Reinisch, Zweiter Teil : Gesteine, new edition, illustrated; Geologische Charakterbilder, edited by Prof. H. Stille, Heft 9 and ro, illustrated; Geologie der Steinkohlenlager, Prof. H. Dannenbers, Zweiter Teil, illustrated. Cambridge University Press.-The Work of Rain and Rivers, Prof. T. G. Bonney, F.R.S.; Rocks and their Origin, Prof. G. A. J. Cole; The Origin of Earthquakes, Dr. C. Davison; Glaciers and Ice Sheets, Prof. Garwood; The Earth, Prof. Poynting, F.R.S.; Natural Caves and Fissures, Dr. A. Rule; Submerged Forests, C. Reid, F.R.S. W. Heinemann.-A History of Scenery: a Geological Reader, R. G. A. Bullerwell. T. C. and E. C. Jack.Geology, Prof. T. G. Bonney, F.R.S. T. Fisher Unwin.-The Building of the Alps, Prof. T. G. Bonney, F.R.S., illustrated. J. Wilev and Sons (New York).-Building Stones and Clays, E. C. Eckel, illustrated.

\section{Mathematical and Physical Science.}

D. Appleton and Co.-The Sun, C. G. Abbot, illustrated. Cambridge University Press.-Clouds, C. T. R. Wilson, F.R.S.; The Physical Basis of Music, A. Wood: The Meteorology of the Globe, Dr. IV. N. Shaw, F.R.S.; Beyond the Atom, Prof. J. 
Cox; The Measurement of Time, the Astronomer Royal; Principia Mathematica, A. N. Whitehead, F.R.S., and B. Russell, vol. ii.; Differential Geometry, Dr. A. R. Forsyth, F.R.S.; Statics, Prof. S. L. Loney; Structure of the Atmosphere, C. J. P. Cave. Gauthier-Villars (Paris).-L'Electricité et 1'Optique, A. Potier, illustrated; Leçons sur les principes de 1'Analyse, R. Adhémar, Tome i., illustrated; Grandeur et Figure de la Terre, J. B. J. Delambre, illustrated; Calcul des Probabilités, Carvallo; Passage de l'Electricité à travers les Gaz, Thomson; Leçons d'Optique, Drude, Tome ii. W. Heinemann.--Introductory Electricity and Magnetism, C. W. Hansel; Experimental Mensuration: an Elementary Text-book of Inductive Geometry, H. S. Redgrove. Hodder and Stoughton.--The Electrical Properties of Flames and of Incandescent Solids, H. A. Wilson. H. Holt and Co. (New York). Elements of Physics, E. H. Hall. T. C. and E. C. Jack.-Radiation, Dr. P. Phillips; Light, according to Modern Science, Dr. P. Phillips; Weather-science, G. F. K. Lempfert; Lord Kelvin, Dr. A. E. Russell; Sir IV. Huggins and Spectroscopic Astronomy, E. W. Maunder. Longmans and Co.-1 Treatise on the Inalytic Geometry of Three Dimensions, Dr. G. Salmon, F.R.S., new edition, revised by R. A. P. Rogers, 2 vols., vol. ii. Macmillan and Co., Ltd.Studies in Terrestrial Magnetism, Dr. C. Chree, F.R.S. (Science Monographs); Studies in Radioactivity, Prof. W. H. Bragg, F.R.S. (Science Monographs). Mills and Boon, Ltd.-Graphs in Arithmetic, Algebra and Trigonometry, W. J. Stainer, illustrated. John Murray.-A New Geometry, A. E. Layng. $R$. Oldenbourg (Munich and Berlin).-.-Einführung in die Mathematische Behandlung der Naturwissenschaften, Kurz gefasztes Lehrbuch der Differential- und Integralrechnung mit besonderer Berücksichtigung der Chemie, Profs. W. Nernst and A. Schönflies, new edition, illustrated. G. P. Putnam's Sons.-Astronomy in a Nutshell, G. P. Serviss, illustrated; $A$ Beginner's Star Book, K. McKready, illustrated. W. Rider and Son, Ltd.-Mathematical Theory of Spirit, H. S. Redgrove. The University Tutorial Press, Ltd.-Mathematical Physics, vol. i., Magnetism and Electricity : a Mathematical Treatment for Students of Physics, C. W. C. Barlow; Qualitative Determination of Organic Compounds: a Systematic Treatment of Advanced Practical Organic Chemistry, J. W. Shepherd; Junior Heat: for the Cambridge Junior Local Examination, Dr. J. Satterly. J. Wiley and Sons (New York).-Practical Mathematics for Second Year Students in Applied Electricity Courses, E. H. Koch, jun.; An Introduction to General Thermodynamics, Prof. H. A. Perkins.

\section{Medical Science.}

F. Alcan (Paris).--Bréviaire de l'Arthritique, Dr. M. de Fleury; Les Opiomanes: Mangeurs, Buveurs et Fumeurs d'Opium, Dr. R. Dupouy; La Fatigue et le Repos: 1a Fatigue, la Conservation des Forces, la Médication par le Repos, Dr. F. Lagrange; Les Sporotrichoses, Drs. de Beurmann and Gougerot; Traitement des Neurasthéniques, Dr. P. Hartenberg; Manuel de Kinesithérapie, Drs. Wetterwald and others, 2 vols. Edward Arnold.-Practical Anatomy, F. G. Parsons and Dr. W. Wright, 2 vols., illustrated; Caisson Disease and Diver's Palsy, Dr. L. Hill, F.R.S.; Lead Poisoning and Lead Absorption: the Symptoms, Pathology, and Prevention, with Special Reference to their Industrial Origin and an Account of the Principal Processes involving Risk, Dr. T. M. Legge and K. W. Goadby; The Protein Element in Nutrition, Major D. McCay; Shock: the Pathological Physiology of some Modes of Dying, Prof. Y. Henderson; NO. 22 I I, VOI. $8 \mathrm{~g}]$
The Carrier Problem in Infectious Disease, with Particular Reference to Enteric Fever, Diphtheria, Cerebro-spinal Meningitis, Bacillary Dysentery, and Cholera, Drs. J. C. G. Ledingham and G. F. Petrie. Baillière, Tindall and Cox.-Veterinary Toxicology, G. D. Lander; Foods: their Origin, Manufacture, and Composition, W. Tibbles. John Bale, Sons and Danielsson, Ltd.-Translations of Prof. Hermann Sahli's Tuberculin and Innere Sekretion: Ihre Physiologischen Grundlagen und ihre Bedeutung für die Pathologie, Prof. A. Biedl. Cassell and Co., Ltd.-British Red Cross Society Training Manual, I. Cantlie; Health Culture for Busy Men, illustrated; Health Habits and How to Train Them, illustrated; Healthy Brain and Healthy Body, illustrated; A System of Surgery, edited by Drs. C. C. Choyce and J. M. Beattie, 3 vols., illustrated. Gustav Fischer (Jena). - Hermiszbildungen: ein Atlas von Querschnitten angeborener Herzfehler mit besonderer Berücksichtigung des Verhaltens des Atrioventrikularsystems, Prof. J. G. Mönckberg, illustrated; Die Ursachen des chronischen Magengeschwürs, J. W. T. Lichtenbelt, illustrated; Das Bakterien-Anaphylatoxin und seine Bedeutung für die Infektion, Dr. H. Dold; Ueber die Regenerationsvorgänge in den Nieren des Menschen, Dr. A. Tilp, illustrated: Die Blutbildung und seine klinische Verwertung, Dr. V. Schilling, illustrated; Intoxications-Psychosen, Dr. F. Kanngiesser. Hodder and Stoughton.--Infectious Diseases and their Preventive Treatment, E. C. Seaton. $T$. C. and E. C. Jack.-Hypnotism, Dr. A. Hutchison. H. Kimpton. A Text-book of Dental Histology and Embryology, including Laboratory Directions, Prof. F. B. Noyes, illustrated. Longmans and Co.-A Manual of Surgical Treatment, Sir W. Watson Cheyne, Bart., F.R.S., and F. F. Burghard, with the assistance of T. P. Legg and A. Edmunds, new edition, in five volumes, vol. ii. Macmillan and Co., Ltd.-Anæsthetics and their Administration: a Text-book for Medical and Dental Practitioners and Students, Sir F. W. Hewitt, M.V.O., new edition, illustrated. Methuen and Co., Ltd.-The Science of Hvgiene: a Text-book of Laboratory Practice, Dr. W. C. C. Pakes, edited and revised by Dr. A. T. Nankivell, illustrated. G. Routledge and Sons, Ltd.--Return to Nature, authorised Translation of " Kehrt zur Natur Zurück," A. Just, bv H. A. Nesbitt, illustrated. The University Tutorial Press, Ltd.-Text-book of Hygiene for Teachers: an Account of School Hygiene based on Elementary Physiology, Dr. R. A. Lyster.

\section{TeCHNOLOGy.}

A. and C. Black.-Tea, E. A. Browne (Peeps at Great Industries), illustrated. Gebrüder Borntraeger (Berlin).-Metallographie, Dr. W. Guertler, Erster Band, Heft ro. Cassell and Co., Ltd.-Wool Carding and Combing, Prof. A. F. Barker and E. Priestley, illustrated; The Steel Square Simply Explained, illustrated; Bevels and Cuts: Easy Methods of Marking Them, E. Hardy; Incubators and Chicken-rearers. Constable and Co., Ltd.-Commercial Paints and Painting, A. S. Jennings; Brewing and Distilling, J. Grant. John Lane.-Bricks and Mortar, F. I. Thomas. Crosby Lockwood and Son.-Crushing and Grinding Machinery Practice: a Handbook on the Machinery used in Crushing and Grinding Operations on all Classes of Materials, T. G. Marlow, illustrated. Methuen and Co., Ltd.Gem-stones, and their Distinctive Characters, Dr. G. F. H. Smith, illustrated. John Murray.-Cocoa: its Cultivation and Preparation, W. H. Johnson, illustrated. Sir Isaac Pitman and Sons, Ltd.-Tobacco: from Grower to Consumer, A. E. Tanner; Wool : from the Raw Material to the Finished Product, J. A. 
Hunter; Coal : its Origin, Method of Working, and Preparation for the Market, F. H. Wilson. T. Fisher Unwin.-Unwin's Technological Dictionary, three parts, in French, German, and English, edited by Dr. A. Tolhausen, revised by $\mathrm{L}$. Tolhausen, with a supplement, including all modern terms and expressions in electricity, telegraphy, and telephony. Whittaker and Co.-Manufacture of Nitro-lignin and Sporting Powder, E. H. Durnford, illustrated; The Radiotelegraphists' Guide and Log-book: a Manual of Wireless Telegraphy for the Use of Operators, W. H. Marchant, illustrated. J. Wiley and Sons (New' York).-Handbook of Sugar Analysis, C. A. Browne, jun.; German and American Varnish-making, Prof. Max Bottler, translated, with notes on American varnish and paint manufacture, by A. H. Sábin, illustrated; Analysis of Paint and Varnish Products, Dr. C. D. Holley.

\section{Miscellaneous.}

Baillière, Tindall and Cox.-The Economics of Feeding Horses, Prof. H. A. Woodruff. Cambridge University Press.-The Psychology of Insanity, Dr. B. Hart; Metals, F. E. C. Lamplough; Prehistoric Britain, L. McL. Mann. Chatto and Windus.-A History of Babylonia and Assyria from Prehistoric Times to the Persian Conquest, L. W. King, vol. ii., illustrated. W. Heinemann.-Introductory Science, W. Tunna Walker. T. C. and E. C. Jack.-Introduction to Science, W. C. D. Whetham, F.R.S.; The Meaning of Philosophy, Prof. A. E. Taylor; Psychology, Dr. H. J. Watt. Macmillan and Co., Ltd.-Manual of Statistics, the late Sir R. Giffen, F.R.S. Milner and Co.-Dactylography : or Finger Prints in Relation to Evidence of Man's Genetic Descent, \&c., H. Faulds, illustrated. John Murray. -Science of the Sea: an Elementary Handbook of Practical Oceanography for Travellers, Sailors, and Yachtsmen, prepared by the Challenger Society for the Promotion of the Study of Oceanography, and edited by Dr. G. Herbert Fowler, illustrated. G. P. Putnam's Sons.-Nature's Harmonic Unity: a Treatise on its Relation to Proportional Form, S. Colman. J. Wiley and Sons (New York).-Fire Prevention and Fire Protection, J. K. Freitag; Applied Methods of Scientific Management, F. A. Parlihurst, illustrated.

\section{UNIVERSITY AND EDUCATIONAL INTELLIGENCE.}

CAMBRIDGE.--In a letter to the Vice-Chancellor, dated March 7, Viscount Esher states that a generous benefactor, who stipulates that his name shall not be mentioned, has placed in his hands a sum of $20,000 l$. for the purpose of endowing a professorship at Cambridge in connection with the experimental study of heredity and of development by descent. It is stipulated also that the new chair shall be called the Balfour Professorship of Genetics. The same benefactor "is willing to furnish such funds as may be necessary to provide and equip a small station at Cambridge for the use of the professor should such a course be considered desirable after careful examination of the methods likely to be most satisfactory for the purposes of research in the domain of genetics."

Lord Rayleigh, Chancellor of the University, has been nominated to represent the University on the occasion of the celebration in July next of the two hundred and fiftieth anniversary of the foundation of the Royal Society; Sir T. Clifford Allbutt, K.C.B., and Dr. Macalister, professor of anatomy, to represent the University at the bicentenary festival of the NO. $22 \mathrm{II}$, VOL. 89]
Medical School of Trinity College, Dublin, in July next; and Dr. E. W. Brown to represent the University at the centenary anniversary of the Academy of Natural Sciences of Philadelphia in the present month.

Syndicates have been appointed to obtain plans for the extension of the School of Agriculture on the Downing site, and for the erection of the building for the Forestry Department at the south-east corner of the same area, and the Vice-Chancellor has been authorised to obtain tenders for the extension of the engineering laboratory.

The next combined examination for fifty-seven entrance scholarships and a large number of exhibitions, at Pembroke, Gonville and Caius, Jesus, Christ's, St. John's, and Emmanuel Colleges, will be held on Tuesday, December 3, and following days. Mathematics, classics, natural sciences, and history will be the subjects of examination at all the abovementioned colleges.

THE new hygiene and physiology laboratories of the Battersea Polytechnic will be opened on Monday, April 22, by the Master of the Worshipful Company of Drapers, his honour Judge Benson, who will deliver an address and distribute prizes and certificates.

Prof. A. Willey, F.R.S., and Dr. W. F. N. Woodland have been elected fellows of University College, London. Dr. Woodland, who is assistant professor of zoology at the college, has been appointed to the chair of zoology at the Muir Central College, Allahabad, India.

THE London County Council has arranged for maintenance grants of $5500 l$., i I, $460 l$., and ir, 6 Iol., respectively, to be paid to the University of London

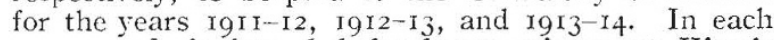
year roool. is intended for home science at King's College for Women, 5 ool. for libraries, $500 l$. for the physiological laboratory, and 5ool. for advanced lectures; 200ol. each year is intended for general university purposes. In each of the years r9I2-I3 and $1913^{-14} 5400 l$. is intended for the university professoriate and for the encouragement of French and other Romance languages.

IN the Popular Science Monthly for February, Prof. A. F. Chamberlain directs attention to some interesting characteristics of the modern English language, which he considers may conduce towards English becoming the universal language of the future. These characteristics include the power of importing and assimilating foreign words when required for the exigencies of intercommunication without subordination to grammatical categories and merely formal canons; the formation of hybrid words, the use of prefixes and suffixes, and the reduction of long words by abbreviated forms. The author quotes the word " remacadamising" as an instance built up from five different languages-Latin, Gaelic, Hebrew, Greek, and English. He considers that no other language in the world possesses the same qualities, which, by the way, somewhat reflect England's qualities as a free-trade colonising nation, and may be intimately connected with our national characteristics.

IN the House of Commons on March 6 Sir Philip Magnus asked the Prime Minister whether the Government has made itself responsible for the housing of the University of London throughout its history; whether he was aware that in the Treasury minute of February I6, I899, the liability to provide a suitable home for the University is acknowledged; 